\title{
THE CAMPAIGN AGAINST RHEUMATISM
}

In a most stimulating article in the Annals of Internal Medicine (February, 1948, p. 368) Dr. P. S. Hench calls attention to the vastness of the problem in America and this country and the necessity for more support, both from the Governments and from the public if this scourge is to be tackled adequately.

"In every country the same findings have been made: (1) rheumatic diseases outrank all others as a cause of chronic morbidity; (2) rheumatic disease annually involves each country in great expense; (3) adequate facilities for the care of most rheumatic patients are non-existent."

Hench quotes staggering figures for the United States and compares their prospects with those of others, "for example for 680,000 tuberculous patients there are available about 100,000 free beds and 100,000,000 dollars annually for care and research but for $6,850,000$ rheumatic patients there are available only about 200 free beds and 200,000 dollars annually for care and research. In other words, although there are ten times as many rheumatic as tuberculous patients, the latter have available 500 times more beds and money. Thus the tuberculous patient, happily thereby a vanishing race, receives 5,000 times as much attention as the non-vanishing rheumatic."

He points out that a survey of voluntary health agencies in America discloses the astonishing paradox that "the greater the need the less the public support" but considers that this is due simply to the fact that the public has not been sufficiently informed or aroused (see Table).

Turning to this country the writer comes to the same conclusions. "In England and Wales before the war there were 30,000 beds for tuberculous patients and only 1,000 for the rheumatic"; and he quotes the well-known fact that rheumatism costs the people of England and Wales 25 million pounds annually and constitutes " the greatest single enemy of social well-being and economic efficiency in Great Britain". It is " a major health problem in Scottish industrial life ".

"In Sweden where most workers are insured, rheumatic cripples become pensionable and were doing so at the rate of 5,000 each year."

Dr. Hench reviews the progress made and the setback caused by the war to the campaign against rheumatism. 'Many rheumatism societies have been formed in America and there are "scores" of rheumatism clinics, whereas before 1910 there were none. The membership of the American Rheumatism Association is now more than 400. Whereas in this country physicians with a special knowledge of the rheumatic diseases were employed during the war in general medical duties, those in the American Services were wisely used on more specialized duties so that certain clinical studies were continued.

In 1936 the Canadian Rheumatism Association was formed and has a close liaison with the American Association as well as being part of the PanAmerican League Against Rheumatism.

Dr. Hench has many kind words to say about the Empire Rheumatism Council; for its plans, for its achievement in obtaining an assurance from the Government that rheumatic patients will be fully

TABLE

DISEASE PREVALENCE VERSUS VOLUNTARY PUBLIC SUPPORT

\begin{tabular}{|c|c|c|c|c|c|c|}
\hline \multicolumn{2}{|l|}{ Disease } & Support & $\begin{array}{l}\text { Amount collected } \\
\text { "annually" }\end{array}$ & Patients & $\begin{array}{c}\text { Dollars available } \\
\text { per patient }\end{array}$ & \\
\hline Infantile paralysis & . & Sold to public & $\$ 16,600,000$ & $\begin{array}{r}175,000 \\
\text { crippled }\end{array}$ & $94 \cdot 00$ & $\bullet$ \\
\hline Tuberculosis & $\ldots$ & Sold to public & $\$ 15,000,000$ & 680,000 & $22 \cdot 00$ & \\
\hline Cancer $\quad \cdots$ & . & $\begin{array}{l}\text { Partly sold to } \\
\text { public }\end{array}$ & $\$ 4,000,000$ & $\begin{array}{c}500,000 \\
\text { under treatment }\end{array}$ & $8 \cdot 00$ & \\
\hline Diabetes $\quad \ldots$ & . & $\begin{array}{l}\text { Not sold to } \\
\text { public }\end{array}$ & $\$ 30,000$ & 660,000 & .05 & \\
\hline Heart disease & . & $\begin{array}{l}\text { Not sold to } \\
\text { public }\end{array}$ & $\$ 100,000$ & $3,700,000$ & .03 & \\
\hline $\begin{array}{l}\text { Rheumatism and } \\
\text { arthritis }\end{array}$ & $\cdots$ & $\begin{array}{l}\text { Not sold to } \\
\text { public }\end{array}$ & $?$ & $6,850,000$ & $?$ & \\
\hline
\end{tabular}


provided for under the National Health Act, and for its efforts in the fields of education and research. He points out that the Annals of Rheumatic Diseases is the only European journal dealing specifically with the problem of rheumatism. "Above all the Council has effectively aroused British public opinion, the controlling force of official action."

The article will be a source of stimulus and encouragement to workers in this difficult field throughout the world. One cannot do better than quote the final paragraph in its characteristic vein. "Regardless of details the international campaign is proceeding and is succeeding modestly. To 'rheumatology' more and more physicians are devoting much or all of their time. But for full success the public must support these physicians.
It is not correct to say that the public gets only what it wants or deserves and that if the public really wanted a cure for rheumatism or cancer it could obtain it by adequate support. Even with the latter the public could hardly ' buy' the remedy in a year or a decade. But unfortunately much of the rheumatic public ignores the useful remedies now available. Individual initiative being what it is, the public has largely received benefits it did not request. It did not ask for the telephone, automobile, or radio. But for good or ill it got them. Thus national action is largely of value as it enhances the opportunities of the individual worker and utilizes his contributions. To that all-important end united effort must be obtained."

Oswald Savage. 